\title{
Standardization of wild Krushnatulasi (Ocimum tenuiflorum Linn) Leaf
}

\author{
Research Article
}

\author{
Meena Shamrao Deogade ${ }^{1}$, Prasad KSR ${ }^{2}$ \\ .1. Professor Department of Dravyaguna \\ Mahatma Gandhi Ayurved College Hospital \& Research Centre, Salod (H), Wardha. M.S. \\ 2. Professor \& Head Department of Panchakarma, \\ YMT Ayurvedic Medical College \& Hospital. P.G.Institute, Kharghar, Navi Mumbai, MS , India.
}

\begin{abstract}
Background: For acceptance and globalization of Ayurveda there is needed to analyze herbal drugs according to modern techniques. Assessment of complete and accurate pharmacognostical study of herbs used in Ayurveda provides scientific basis of its quality. Objectives: To standardize the Kushnatulasi (Ocimum tenuiflorum Linn/ Ocimum sanctum L) collected from wild. Materials and Methods: The present study includes organoleptic, microscopic physicochemical, phytochemical and chromatographic examination of leaf of Kushnatulasi. Results: macro and microscopic, organoleptic, physicochemical, phytochemical and chromatographic findings are observed as per API in present study. Conclusion: Standardization of Krushnatulasi (Ocimum tenuiflorum Linn) is useful in authentication of genuine drug.
\end{abstract}

Keywords: Krushnatulasi, Ocimum tenuiflorum Linn, Ocimum sanctum L, Standardization, wild, Pharmacognostic.

\section{Introduction}

In ancient Ayurveda texts the concept of standardization and quality control of drugs is found. Physician used to collect the drugs himself with the help of Shabda (sound), Sparsha (texture), Roopa (color), Rasa (taste), Gandha (smell) and also based on habitat, morphology etc. in those days. After checking all these factors the drug would be used as a medicine. The nomenclature of many herbs denotes their physical, chemical characteristic and therapeutic uses which are considered as primitive standardization parameters (1). Surasa, Sulabha, Surabhee, Shulaghnee, Bahumanjaree, Bhutaghni these synonyms of Krushnatulasi depicted its useful form (juice) in many diseases, easy availability, aroma, efficacious in colic, morphological character and antimicrobial action respectively.

In current period recent advances has identified many test and parameters to evaluate quality control of drugs by pharmacognostic studies. So it is very essential to lay down pharmacognostic study of medicinal plants which are used in various formulations. It deals with authentication and standardization of natural drugs. Authentication and

*Corresponding Author:

Meena Shamrao Deogade,

Professor, Department of Dravyaguna,

Mahatma Gandhi Ayurved College Hospital \& Research Centre,

Salo (H), Wardha (MS),

E-mail:drmmeena@rediffmail.com standardization evaluated by morphological or organoleptic tests, microscopic, chemical, and physical evaluation, chromatography, spectrophotometry etc. Pharmacognostic study includes parameters which help in identifying drug in dry powder form also. This is again necessary because once the plant is dried and made into powder form, it loses its morphological identity (2). Therefore it is necessary to provide standard parameters for the quality control of Ocimum tenuiflorum Linn (Krushnatulasi) leaves which can be beneficial for further quality control researches.

\section{Krushnatulasi (Ocimum tenuiflorum Linn)} or Queen of herbs has been used in Ayurveda for its varied healing properties. Krushnatulasi the Holy basil, the legendary 'Incomparable one' of India, is one of the holiest and most cherished of the many healing and healthy giving herbs of the orient (3).

\section{Materials and Methods \\ Sample Collection}

The leaves of Ocimum tenuiflorum Linn (Krushnatulasi) were collected as per GPS co-ordinator during the period of 21 July to 30 September 2015 from village Dabha, Wardha District (M.S.). These leaves were collected from open shrub land.

\section{Authentication}

The herbariums of Ocimum tenuiflorum Linn was prepared by standard method $(4,5)$ and sent for identification to Botanical Survey of India, Pune, Maharashtra. 


\section{Preservation}

After authentication of plant, the leaves of this plant collected from mature source plants. While collecting the leaves precaution was taken to avoid the insect-damaged plants. Leaves were subjected for washing under the tap water to remove adherent soil, dirt etc. for 2-3 times and finally followed by ethanol wash and then allowed to shade dry at room temperature for seven days. Finally leaves powdered to a coarse powder with mixer grinder and used for powder microscopy. For the histological profile the plant was preserved in a solution of FAA (Formalin 90: Acetic acid 7: Alcohol-3) (6).

\section{Macroscopic and organoleptic evaluation}

Macroscopic characters of the whole plant were studied for the detection of its authenticity. The characters were compared with the description given in the various floras and authenticity of the plant was confirmed. The fresh and dried leaves and their powders were evaluated separately for their macroscopic and organoleptic characters as per the standard methods described in various texts of pharmacognosy $(7,8)$.

\section{Microscopic evaluation}

Free hand sections of the plant material stained with Phloroglucinol and $\mathrm{HCl}$ and observed under the microscope for the presence of primary and secondary metabolites. the same method adopted for the powder samples (9).

\section{Histochemical evaluation}

Thick sections of plant samples subjected to Histochemical tests to find starch grains, tannin, calcium etc. by treating various reagents (10).

\section{Physico-Chemical Study}

Physicochemical analysis provides the objective parameters to set the standards for quality of raw drugs as well as finished products. With the help of analytical studies, it is possible to standardize the drug and differentiate the adulterants (11).

\section{Phytochemical Study}

A phytochemical study of a plant is necessary for understanding the significance of phyto-constituents and for its observed activities. Phyto-chemistry also helps in standardizing the herbal preparations so as to get the optimal concentrations of active constituents (12).

\section{High performance thin layer chromatography (HPTLC) by CAMAG MUTTENZ}

For obtaining the sample for HPTLC $5 \mathrm{mg}$ of ethanol extract of Krushnatulasi Leaves dissolved in $5 \mathrm{ml}$ of ethanol. The plate was pre-washed with Ethanol before application of spots. Sample solutions were applied to the plate as sharp bands by means of Camag Linomat-5 sample applicator. The spots were allowed to dry in a current of air. The mobile phase Toluene: Ethyl acetate: glacial acetic acid in proportion of 7:3:0.1 was poured into a twin trough glass chamber. Then whole assembly was left to equilibrate for $30 \mathrm{~min}$ and the plate was placed in the chamber. The plate was then developed until the solvent front had travelled at a distance of $80 \mathrm{~mm}$ above the base of plate. The plate was then removed from chamber and dried in a current of air. Detection was done with CAMAG TLC scanner3 at a wavelength $254 \mathrm{~nm}$ and $366 \mathrm{~nm}$ and $416 \mathrm{~nm}$.

\section{Observation and Results}

Dabha village situated at $20.57 \mathrm{~N}$ and $78.81 \mathrm{E}$ (Figure 1). Intermittent presence of Krushnatulasi was observed while collecting from field (Figure 2). The voucher specimen number of Ocimum tenuiflorum $\mathrm{L}$. herbarium mentioned as MSD-3 and Authentication Letter No- BSI/WRC/Tech./2014/447, Dated 29-122014 (Figure 3).

\section{A) Macroscopic characters:}

The leaf of Krushnatulasi was $6.2 \times 2.6 \mathrm{~cm}$. elliptic-oblong, obtuse or acute, entire or serrate, pubescent on both sides, minutely gland-dotted. Base is obtuse or acute; petioles $2 \mathrm{~cm}$. long, slender and hairy (Fig-3).

\section{B) Microscopic study of Leaf of Ocimum tenuiflorum Linn}

a) Transverse Section (T.S.) of Petiole:

The diagrammatic T.S. shows Cat face shaped out line with large no. of trichomes with ground tissue consists central large vascular bundle and two meristeles. T.S. of petiole was showed the single layered barrel shaped thin cutinized epidermal cells having simple unicellular trichomes, multicellular, multiserriate, capitates sessile and glandular trichomes followed by 2-4 layered hypodermal cells. Just below the hypodermis, parenchymatous tissue is present. Some of them having chlorophyll, oil globules, The arrangement of vascular region at the centre consists large vascular bundle consists phloem towards lower side and xylem towards upper side along with two meristeles located at the edge of the main vascular bundle. Xylem consists of xylem parenchyma and its fibres and phloem consists of phloem fibres and its sieve elements (Plate 1).

\section{b)Transverse Section through Midrib:}

The diagrammatic T.S. shows boat shaped winged lamina region through mid-rib shows centrally located vascular bundle. Single layer upper epidermal cells interrupted by few multicellular trichomes epidermis covered with thin cuticle; at the region of mid rib the multicellular trichomes are bluish in colour. Lamina consists of upper 2-3 layered of palisade cells without any intra cellular spaces, with oil globules and chlorophyll pigments. 5-6 layers of spongy parenchyma cells at lower region filled with 
chlorophyll with large intra cellular spaces some of the cells lead to stomatal openings (Plate-2).

Trough mid rib gives mechanical support to the centrally situated vascular bundle, below the epidermis followed by 3-4 layers of collenchymatous cells. Which is consists of xylem and phloem covered by ground tissue from both sides. Where in lower epidermal cells are smaller and often intercepted by cystoliths. There are two types of Trichomes. Epidermal Trichomes are densely distributed both on the adaxial and abaxial surfaces of the lamina.

(i) Glandular Trichomes: these are secretary structures bearing aromatic compounds. Two types of glandular Trichomes are seen (Plate-2).

(a) Peltate type of trichome: These are 'Bowl' shaped Trichomes with single short and wide stalk cell and cup shaped body. These peltate Trichomes are usually situated in shallow cavities of the Lamina. The body of the trichome is multicellular with radiating cells of darkly strained cell contents. The glands are $25 \mu \mathrm{m}$ in height and $60 \mu \mathrm{m}$ in diameters.

(b) Capitate type of trichome: These are multicellular Trichomes with thick, wide stalk cell and multi-cellular spherical body. The body consists of mostly 4 cells and possesses dense aroma compounds. These glands are $40 \mu \mathrm{m}$ in height and body is $35 \mu \mathrm{m}$ thick.

(ii) Non-Glandular Trichomes: These Trichomes are multicellular, uniserrate and un-branched. They have broad basal part and gradually tapering pointed terminal part. The trichome is $150 \mu \mathrm{m}$ long and 20 um thick at the base (Plate-2).

C) Lamina: The lamina is bifacial with distinction into adaxial side and abaxial side. An adaxial epidermis consists of fairly wide, spindle shaped cells with prominent cuticle. The cells are $20 \mu \mathrm{m}$ thick. The abaxial epidermis is comparatively thin, rectangular in shape and the cuticle is prominent. The mesophyll tissue consists of an adaxial band of single row of cylindrical, compact palisade cells which are $70 \mathrm{um}$ in height. The lower part of the lamina includes 4 or 5 layer of lobed loosely arranged spongy mesophyll tissue (Plate-3).

\section{Powder Microscopic Study}

Diagnostic characters observed under microscope are dull green; aromatic in odour and fine corse in touch. Diagnostic characters observed under the microscope are shows groups of round to polygonal parenchymatous cells, pitted and spiral vessels, simple multicellular warty trichomes, oil globules and diacytic stomata, Pallisade parenchyma, Oil globules, Stomata,
Calcium oxalate Prismatic crystals, glandular trichomes, Capitate sessile blacklist, crystal fibre, simple fibre, (Plate-4).

Organoleptic study: Orgenoleptic study of Krushnatulasi leaves powder was carried out and the results are depleted in the table 1.

Micrometric study of Krushnatulasi - leaf: The micrometric study of Krushnatulasi leaf $6.2 \times 2.6 \mathrm{~cm}$, Petiole $2 \mathrm{~cm}$. Results are stated in table 2.

\section{Histochemical evaluation of leaf:}

Various Histo-chemical tests were conducted on the leaf powder of Krushnatulasi. Lignified cells, Starch grains, Ca Ox - crystals, Tannin cells, Oil globule observed where as Mucilage was absent (Table-3).

\section{Physico-chemical parameters:}

Physicochemical parameters of Krushnatulasi leaves powder was tested using various physicochemical analysis such as moisture content, ash value, acid insoluble extracts and $\mathrm{pH}$ value was also estimated. The observed results are shown in the table 4 .

\section{Preliminary qualitative chemical test:}

Leaves samples were qualitatively tested for the presence of different phytoconstituents like Carbohydrates, Protein, Reducing sugar, Steroids, Cardiac Glycosides, Saponins, Flavonoids, Alkaloids, and Tannins. The observed results are shown in the table 5 .

\section{High performance thin layer chromatography (HPTLC):}

HPTLC analysis of dried leaves of Krushnatulasi fraction; demonstrated that the normal phase analysis carried out in silica coated plate interpreted around seven fragments resolved within $0.8 \mathrm{RF}$ values. Though silica plate is not that much retentive compared with traditional $\mathrm{C} 18$ gel but these results proved effective for complete separation almost all fractions. This study was performed three different wavelengths; 254, 316 and $416 \mathrm{~nm}$ UV-vis. range. Results obtained in $254 \mathrm{~nm}$ characterised improved peak shape compared with 316 and $416 \mathrm{~nm}$ absorption. Importantly, after analysis most of the fractions eluted together initially. The same results were also observed in all selected wavelengths. It emphasised, the selection of silica phase in not appropriate for separation of non-polar fractions. Nevertheless, considering higher wavelengths proved much better resolution for initial retained fraction.In the middle of the HPLTC plate no any strong peak was observed. But at the end one strong component was eluted. Presumably, this fraction is a polar component that supposed to be protonated in selected mobile phase; the homogenous mixture of toluene and ethyl acetate 
with small fraction of glacial acetic acid. Nonetheless, the HPTLC analysis carried out in normal phase proved effective separation of dried leaves extracts. This normal phase HPTLC technique selected to resolve better fragmentation of non-polar components from Krushnatulasi leaves extracts. As displayed in graph No.1; run the ethanol extract on silica gel plate with selected eluents, toluene, ethyl acetate and glacial acetic acid as modifier. These selected mobile phase optimised the complete separation of all fragments of Krushnatulasi leaves where the glacial acetic acid promote the protonation of acid-base strength components. Within $0.7 \mathrm{RF}$ values around six components were identified. Importantly between 0.2 to 0.9 almost four components eluted together since it is presumed that they might have similar partition coefficient values. In addition, there is very partial resolution among them was occurred. Thereafter very small fractions were observed in the middle and finally one broad and blunt peak was visualised at the end of the separation (Graph No.1,2,3).

\section{Discussion}

The materials are collected from the nearest natural habitat for getting the good natural quality herbs. The Latlons are identified to make precision of the collecting area and to help the future researchers. The Krushnatulasi is not available as a bunch or bundled. The macroscopic features of Krushnatulasi leaves described in various floras are observed in the study. T.S. of Krushnatulasi petiole shows Cat face shaped out line in diagrammatic section with large number of trichomes with ground tissue consists of central large vascular bundle consists of phloem towards lower side and xylem towards upper side along with two meristeles located at the edge. In earlier works done by V Sharma et.al. , mentioned similar findings in pharmacognostic study of Krushnatulasi (13). Diacytic type of stomata was seen on both the surfaces, 4 cells of capitates trichome possess dense aroma compounds and filled with purple colour $(14,15)$.

The values demonstrated for Krushnatulasi in present study are as follows. The Foreign matter was $0 \%$, and moisture content $0.17 \% \mathrm{w} / \mathrm{w}$. The total ashvalue is $0.94 \% \mathrm{w} / \mathrm{w}$. and the acid insoluble ash is 0.053 $\% \mathrm{w} / \mathrm{w}$. The water soluble extractive is $17.65 \% \mathrm{w} / \mathrm{w}$, and alcohol soluble extractive is $9.4 \% \mathrm{w} / \mathrm{w}$. All these values are as per standards of Ayurvedic Pharmacopeia of India and Quality Standards of Indian Medicinal Plants (Table 5.9) $(16,17)$.

As loss on drying values $(\mathrm{T}=0.17)$ of Krushnatulasi indicating that less moisture was present in the collected material. Therefore the chances of microbial growth or contamination, and the presence of fungi or insects and plant material deteriorates quickly in presence of water was decreased. The ash values found as within normal limits (0.94) in present study, denoted the absence of an undue proportion of extraneous mineral matters introduced accidentally or mixed at the time of collection. Acid insoluble ash is the treatment of ash with hydrochloric acid leaves virtually only silica. Minimum acid insoluble ash values $(0.053)$ found in present study indicates less quantity of silica was present in plant material. The maximum water and alcohol soluble extractive values of Krushnatulasi (17.65, 9.4 respectively) are denoting the more amounts of chemical constituents present and are soluble in respective solvents either water or ethanol, indicating the good potency of selected herbal drugs. pH of Krushnatulasi was acidic (5.09) might be because of teekshna guna.

In previous study by Jasmeet et. al., total ash and acid insoluble ash $(15.6 \& 2.5 \% \mathrm{w} / \mathrm{w})$ are more than standard and in comparison with present study. And another study by Sharma et al, express less than standard water soluble extractive and alcohol soluble extractive values $(3.8 \& 4 \% \mathrm{w} / \mathrm{w})$ in comparison with present study. These study values of total ash and acid insoluble ash values are more than present study in comparison and less than the standards $(18,19)$. Rf values detected for identification of alkaloids, Terpenoids, flavonoids and Saponine. 0.13, 0.25, 0.33, $0.48 \mathrm{Rf}$ values reveal the presence of alkaloids. 0.04, $0.07,0.08,0.27,0.72,0.95 \mathrm{Rf}$ exhibits the presence of Terpenoids. Whereas Rf $0.15,0.17$ shows presence of Saponine.

\section{Conclusion}

From the pharmacognostic study it is observed that the quality and potency of drug is good. May be because of the leaves collected are according to the Charaka said method of collection from field. During this (Varsha rutu) period the collected leaves contains highest quality of active principle, so the expected qualities in the plants offers better result in the treatments. It can be concluded that the organoleptic, pharmacognostical, physicochemical values and phytochemical study are useful in authentication and standardization of Krushnatulasi (Ocimum tenuiflorum Linn) while collecting the drug.

\section{References}

1. Meena S. Deogade, Anita Wanjari, Seema C. Lohakare, Pharmacognostical and Phytochemical Study of Costus igneus leaf, J-ISM, V2 (4), OctDec 2014; 174-178.

2. Sumitra Chanda, Importance of pharmacognostic study of medicinal plants: An overview, Journal of Pharmacognosy and Phytochemistry 2014; 2 (5): 69 $-73$

3. Priyabrata Pattanayak et.al, Ocimum sanctum Linn. A reservoir plant for therapeutic applications: An overview, Pharmacogn Rev. 2010 JanJun; 4(7): 95105. doi: 10.4103/09737847.65323, PMCID: 


\section{PMC3249909}

4. Tony Bean, Collecting and preserving plant specimens, a manual, State of Queensland, Department of Science, Information Technology and Innovation April 2013; 2 - 22

5. Jain, S.K., Rao., R.R., 1976. Field and Herberium Methods, Today \& Tomorrow Publishers, New Delhi, 22-61.

6. Donald Alexander Johansen: Plant Micro technique. McGraw-Hill Book Company, Inc.New York and London, 1940.Pg. no. 41.

7. Trease and Evans, Pharmacognosy, $15^{\text {th }}$ Ed., W.B. Sunders Company Ltd. 1996 p.569,570.

8. Khandelwal K. R., "Practical Pharmacognosy Techniques and Experiments" ,23 ${ }^{\text {rd }}$ ed., 2013, Nirali Prakashan Pune, p. n.24-29,149-156.

9. Wallis TE, Text book of Pharmacognosy, $5^{\text {th }}$ Ed., New Delhi: CBS Publishers \& Distributors2002 p. 123-132, 210-215.

10. Jesse W, Li H, Vaderas JC. Drug discovery from natural products: End of an era or an endless frontier. Science 2009;325:161-5.

11. Wallis, T. E., 1985. Text book of Pharmacognosy, 5th Edi. CBS Publishers, New Delhi, 571-578.

12. Birdi T.J., Brijesh S. and Daswani P. G., Approachesb towards the preclinical testings and standerdization of medicinal plants. Foundation for medical research, India.2006

13. Sharma et al, Comperative pharmacognostical and phytochemical evaluation (leaf) of different species of Ocimum, International Journal of Phytopharmacy, 2011, Vol. 1 (2); 43-49.

14. Jasmeet et al.,Standardization of Tulsi (Ocimum sanctum Linn.), Int J Ayu Pharm Chem 2015 Vol. 4 (1);165-175

15. Datta, et al.: Pharmacognostical and analytical study of Tulsi-Amla-Yasti Ghrita,AYU | Apr-Jun 2012, Vol 33(2),274-278

16. Gupta A K et al., Quality Standards of Indian Medicinal Plants, Vol V, Indian council of medicinal research, New delhi, 2005, 275-284

17. Sharma et al, Comperative pharmacognostical and phytochemical evaluation (leaf) of different species of Ocimum, International Journal of Phytopharmacy, 2011, Vol. 1 (2); 43-49.

18. Jasmeet et al.,Standardization of Tulsi (Ocimum sanctum Linn.), Int J Ayu Pharm Chem 2015 Vol. 4 (1);165-175

19. Anonymous, Ayurvedic Pharmacopeia of India, ed.1, 1 (2), 1999, Government of India, Ministry of health and family welfare, Department of Indian systems of medicine and homoeopathy, New Delhi, p 59-62.

Table 1: Organoleptic character of Krushnatulasi leaves powder

\begin{tabular}{|c|c|c|c|c|}
\hline Characters & Colour & Taste & Odour & Nature of powder \\
\hline Observations & Brown & Katu & Aromatic & Coarse \\
\hline
\end{tabular}

Table 2: Micrometric study of Krushnatulasi leaf

\begin{tabular}{|c|c|}
\hline Characters & Measurments \\
\hline \multicolumn{2}{|c|}{ Petiole } \\
\hline Multicellular & $3.7 \times 0.6 \mathrm{~mm}$ \\
\hline Glandular & $1.1 \times 0.5 \mathrm{~mm}$ \\
\hline Sessile & $0.5 \times 0.4 \mathrm{~mm}$ \\
\hline \multicolumn{2}{|c|}{ Midrib } \\
\hline Lamina & $2 \mathrm{~mm}$ \\
\hline Through midrib & $4.5 \mathrm{~mm}$ \\
\hline Sunken sessile trichome & $0.7 \times 0.5 \mathrm{~mm}$ \\
\hline Multicellular & $7.5 \times 0.5 \mathrm{~mm}$ \\
\hline Multicellular Head & $1.2 \times 1.5 \mathrm{~mm}$ \\
\hline Multicellular neck & $0.8 \times 0.7 \mathrm{~mm}$ \\
\hline Collenchyma & 2-3 Layered \\
\hline Palisade Cells & 2 layered \\
\hline Spongy Par & 5-6 Layered \\
\hline Palisade ratio & $1 / 4 \times 2$ \\
\hline Stomata & $0.6 \times 0.4 \mathrm{~mm}$ \\
\hline No. of Stomata & $9 / \mathrm{sq} \mathrm{mm}$ \\
\hline No. Epidermal cells & $24 / \mathrm{sq} \mathrm{mm}$ \\
\hline Stomatal Index & 27.2 \\
\hline
\end{tabular}


International Journal of Ayurvedic Medicine, 2019, 10(1), 52-61

Table 3: Histochemical tests for Krushnatulasi leaf

\begin{tabular}{|c|l|l|l|c|}
\hline Sr. no & \multicolumn{1}{|c|}{ Reagent } & Observation & \multicolumn{1}{c|}{ Characteristics } & O.t. Leaves \\
\hline 1. & Phloroglucinol+ Conc. $\mathrm{HCl}$ & Red & Lignified cells & ++ \\
\hline 2. & Iodine & Blue & Starch grains & ++ \\
\hline 3. & Phloroglucinol+ Conc. $\mathrm{HCl}$ & Dissolved & Ca Ox - crystals & ++ \\
\hline 4. & Fecl ${ }_{3}$ solution & Dark blue & Tannin cells & ++ \\
\hline 5. & Ruthenium red & Red & Mucilage & -- \\
\hline 6. & Sudan III & Red & Oil globule & ++ \\
\hline$++=$ Present, - - = Absent & \multicolumn{2}{|l}{} \\
\hline
\end{tabular}

Table 4: Physicochemical parameters of leaves Krushnatulasi

\begin{tabular}{|l|l|l|}
\hline \multicolumn{2}{|c|}{ Krushnatulasi leaves powder } \\
\hline Test & $\begin{array}{l}\text { API } \\
\text { (Stand. Values })\end{array}$ & Found values \\
\hline Foreign matter & Not $>1.5$ & 0 \\
\hline Loss on drying at $110^{0} \mathrm{C}(\% \mathrm{w} / \mathrm{w})$ & - & 0.17 \\
\hline Ash value $(\% \mathrm{w} / \mathrm{w})$ & Not $>19$ & 0.94 \\
\hline Acid insoluble ash $(\% \mathrm{w} / \mathrm{w})$ & Not $>0.9$ & 0.053 \\
\hline Water soluble extractive value $(\% \mathrm{w} / \mathrm{w})$ & Not $<13.0$ & 17.65 \\
\hline Ethanol soluble extractive value $(\% \mathrm{w} / \mathrm{w})$ & Not $<6.5$ & 9.4 \\
\hline $\mathrm{P}^{\mathrm{H}} 10 \%$ solution & - & 5.09 \\
\hline
\end{tabular}

Table 5: Preliminary Phytochemical investigation of leaves Krushnatulasi

\begin{tabular}{|l|l|l|}
\hline \multicolumn{2}{|c|}{ Qualitative Tests } \\
\hline Sr. & Test & Krushnatulasi \\
\hline 1 & Test for Carbohydrates & + \\
\hline 2 & Test for Protein & - \\
\hline 3 & Test for Reducing sugar & - \\
\hline 4 & Tests for Steroids & + \\
\hline 5 & Test for Cardiac Glycosides & + \\
\hline 6 & Test for Saponin foam test & + \\
\hline 7 & Test for Flavonoids & + \\
\hline 8 & Test for Alkaloids & + \\
\hline 9 & Test for Tannins and Phenolic compounds & + \\
\hline
\end{tabular}

Fig.1: Showing the Latitude and Longitudes of collection area (GPS)

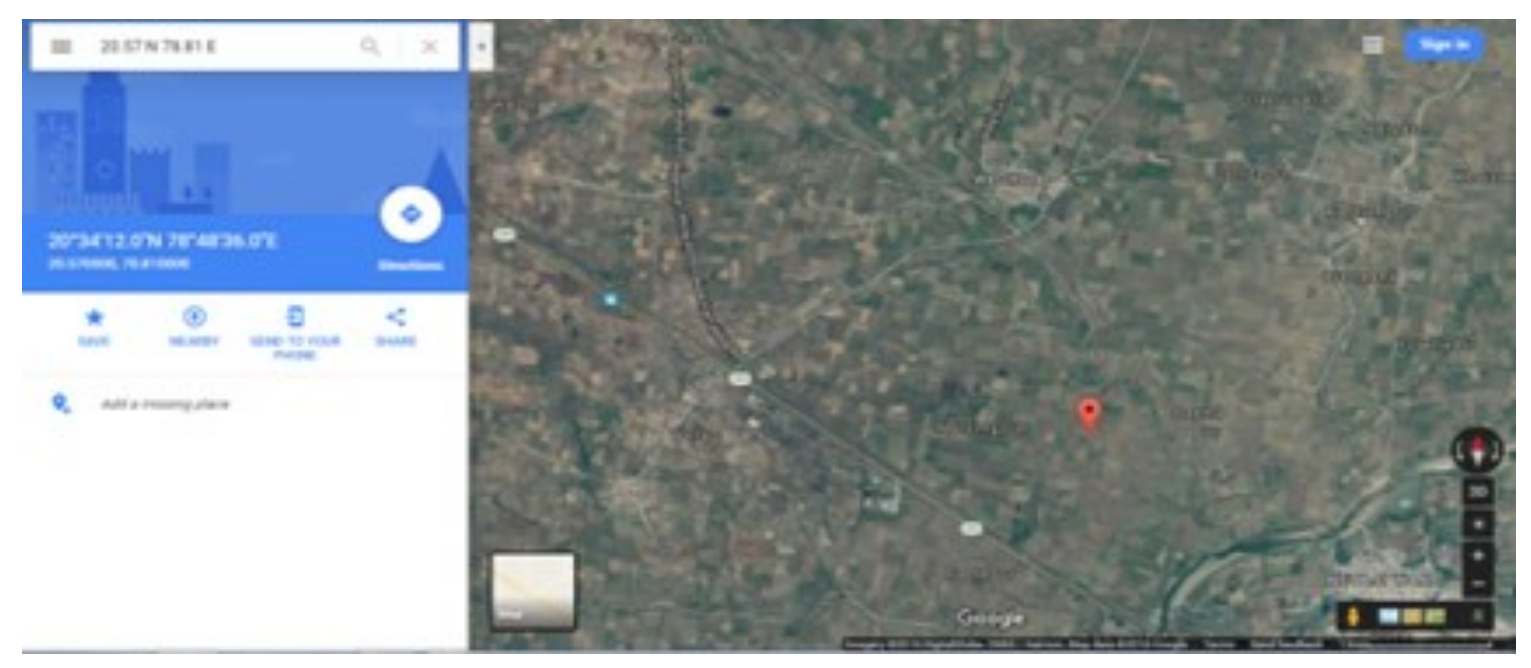


Meena Shamrao Deogade et.a.l., Standardization of wild Krushnatulasi (Ocimum tenuiflorum Linn) Leaf

Fig.2: Natural habitat, collection and preservation of plant material
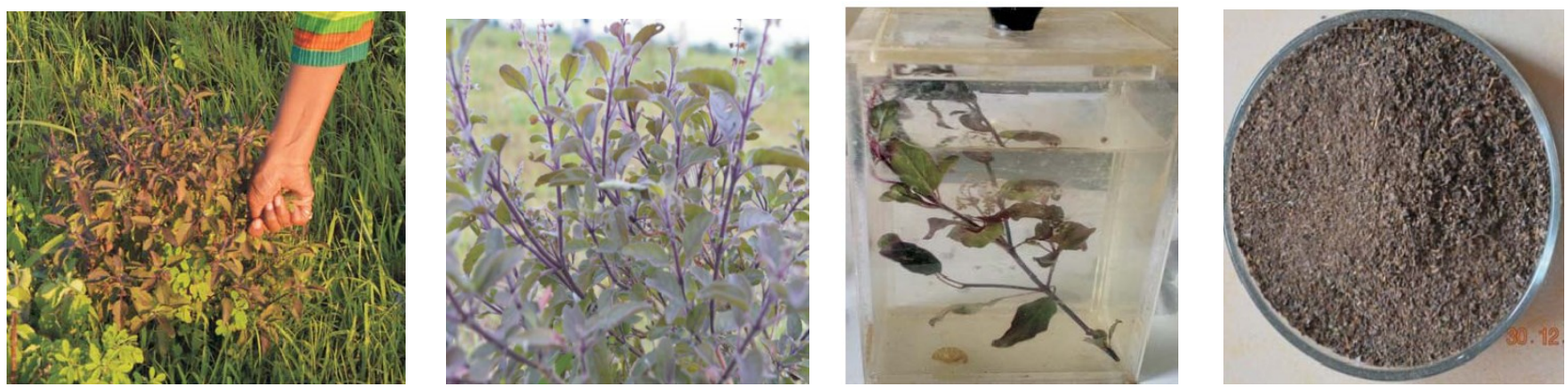

Fig.3: Herbarium, macroscopic study of Ocimum tenuiflorum Linn.
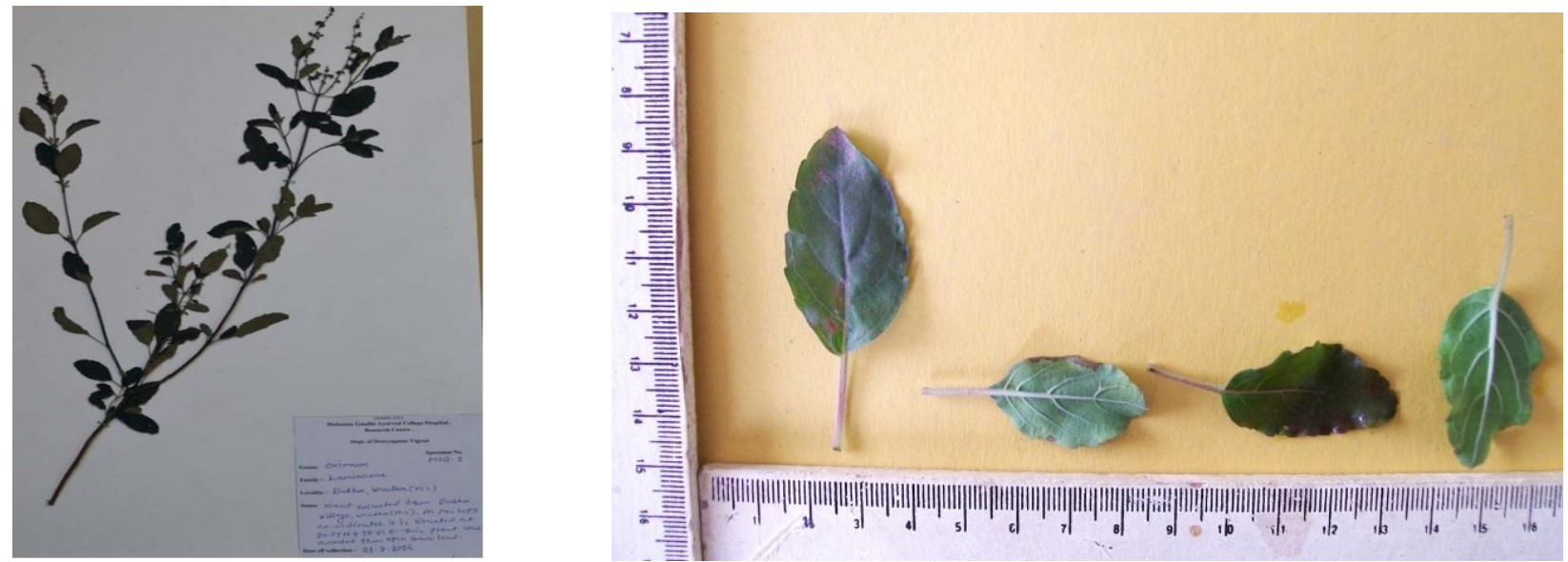

Plate 1: Transverse Section (T.S.) of Petiole

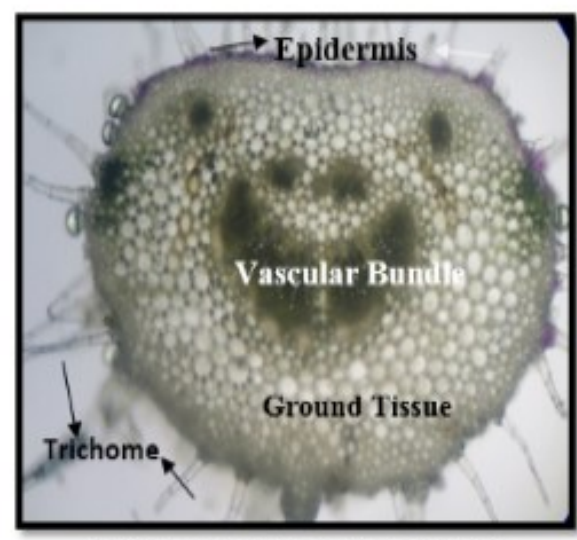

la] Diagrammatic section of Petiole

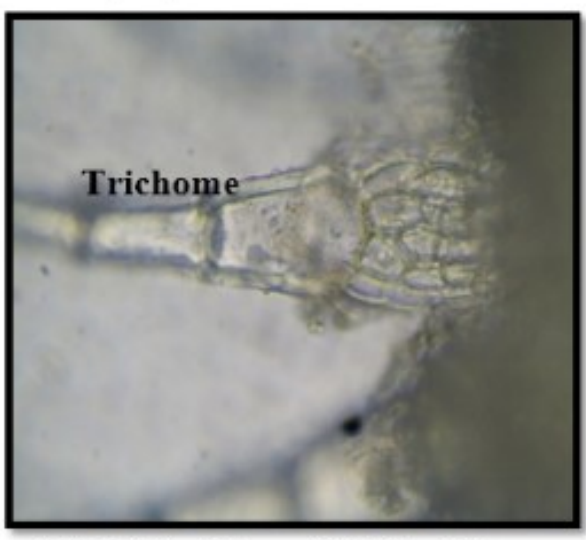

1d] Multiseriate multicellular trichome

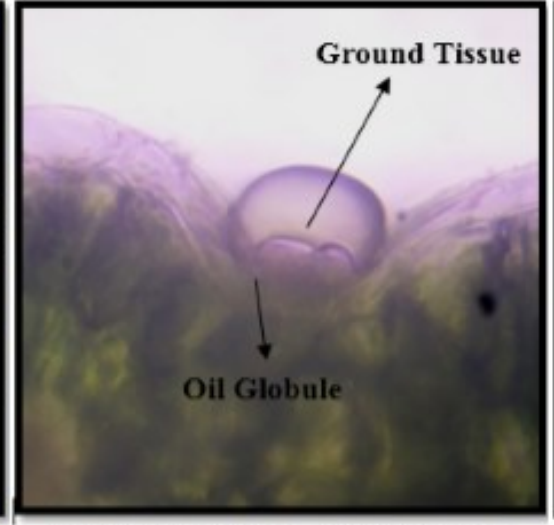

1b] Ground Tissue with Oil Globules

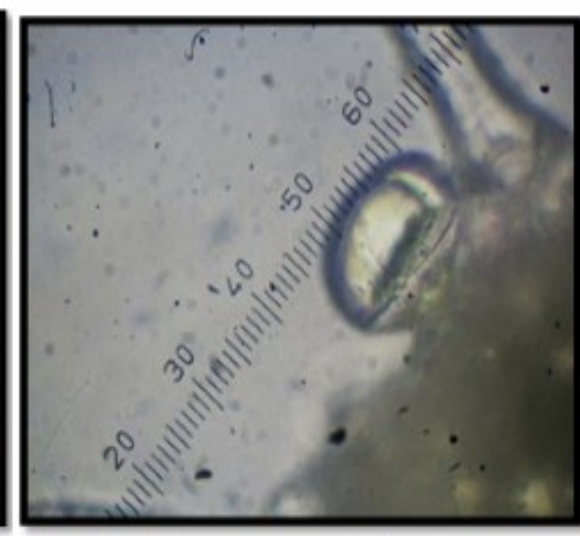

le] Capitates sessile trichome

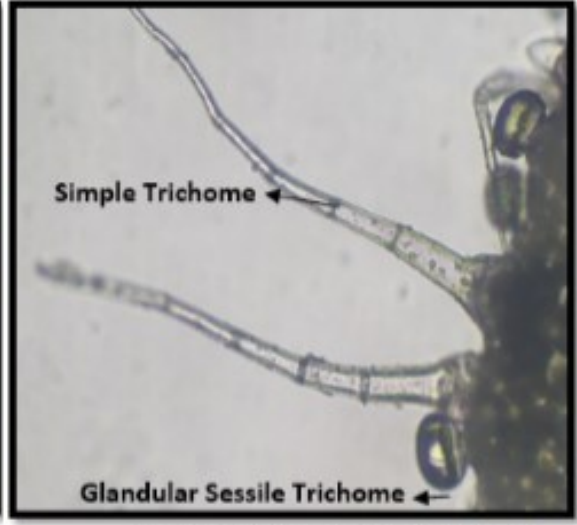

1c] Glandular Sessile Trichome

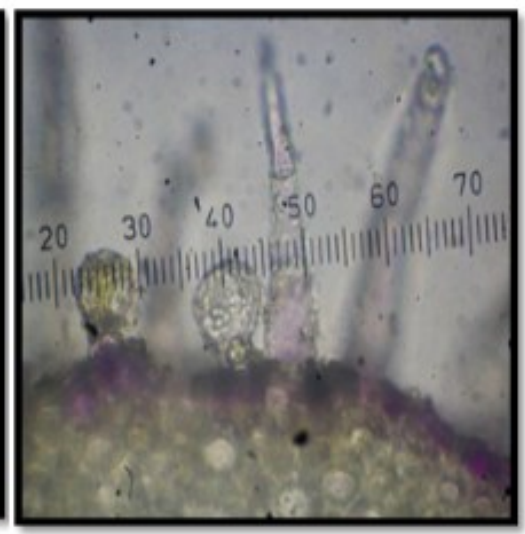

1f] Simple unicellular trichomes 


\section{Plate 2- T.S. through midrib}

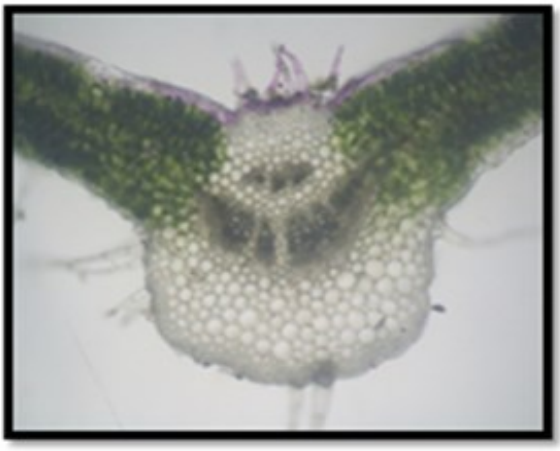

2a] Diagrammatic section through Mid Rib

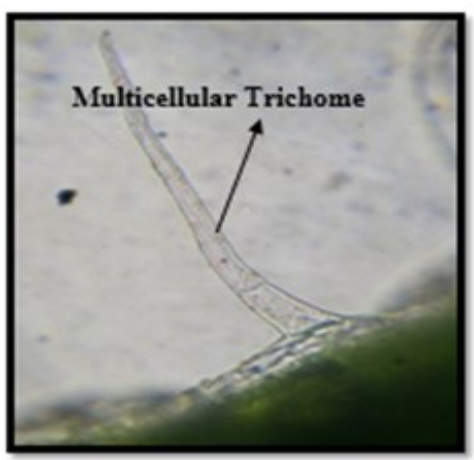

2d

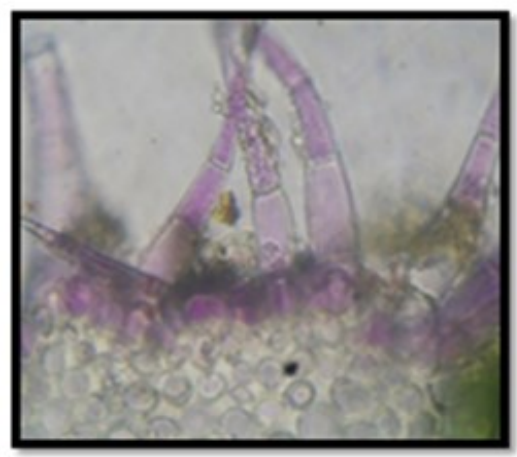

2b] Trichome above through mid-rib filled with purple colour(Krishna)

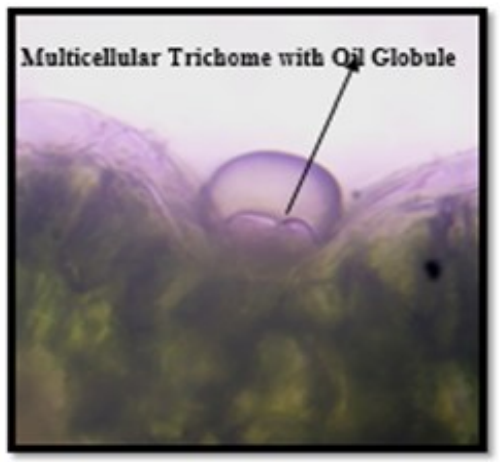

$2 \mathbf{e}$

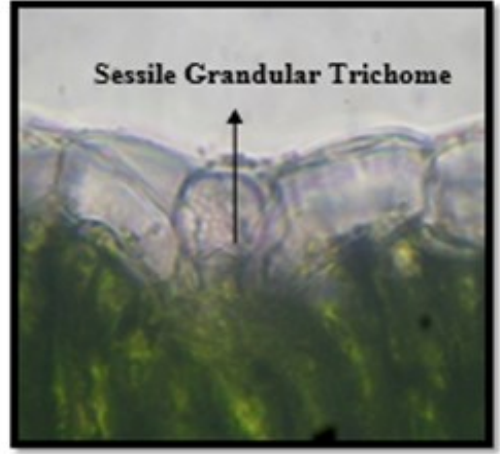

$2 c$

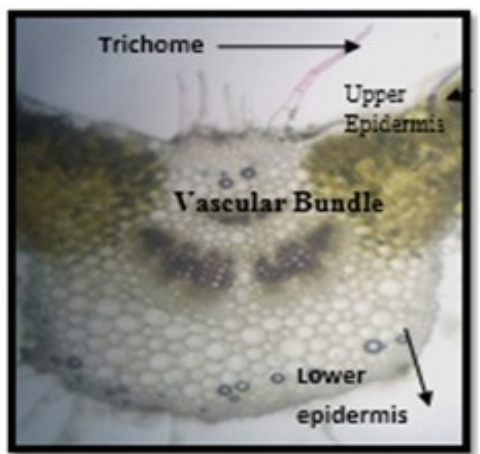

$2 \mathbf{f}$

Plate 3 - Micrometric surface study

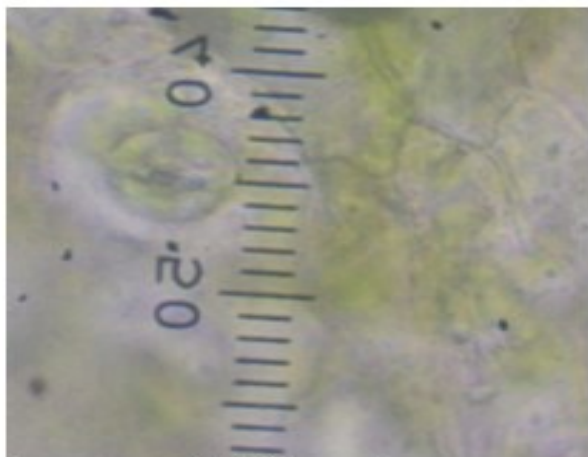

3a] Stomata

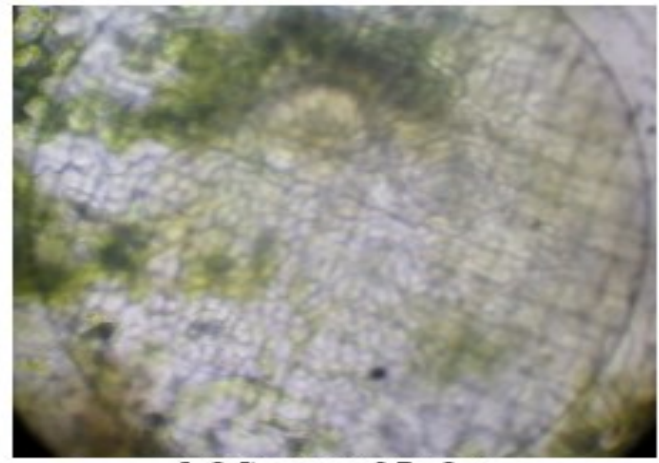

3c] Stomatal Index

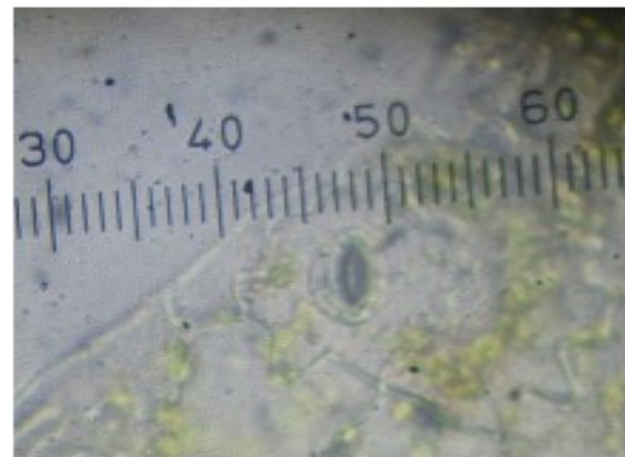

3b] Diacytic Stomata

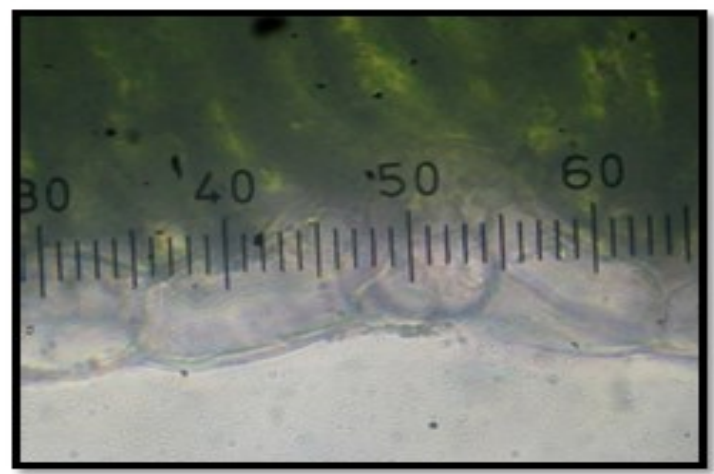

3d] Compact palisade cells 
Plate 4- Powder microscopy

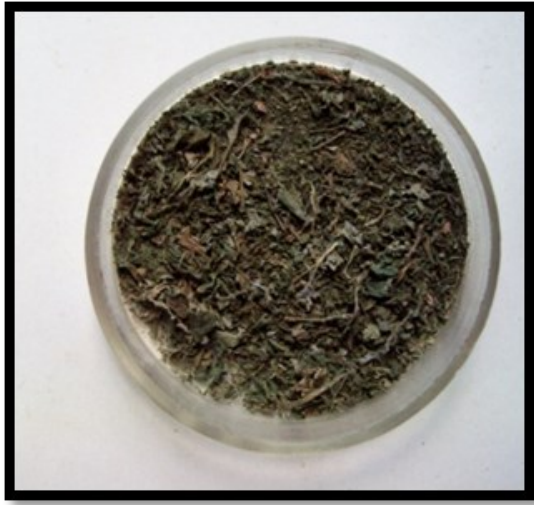

4a] Powder of Krushnatulasi

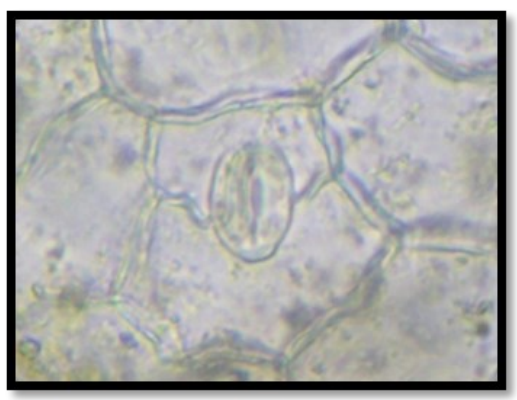

4d] Diacytic stomata

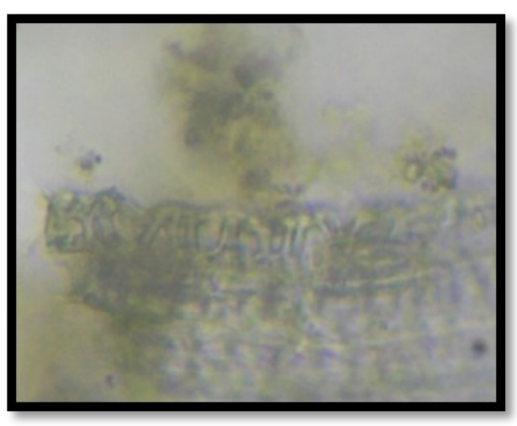

4g] Crystal Fibre

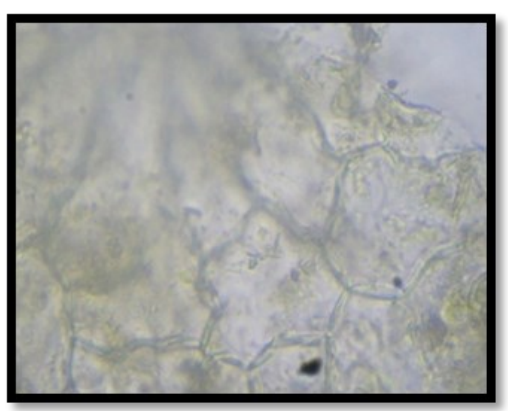

$4 \mathrm{j}]$ Epidermis cells

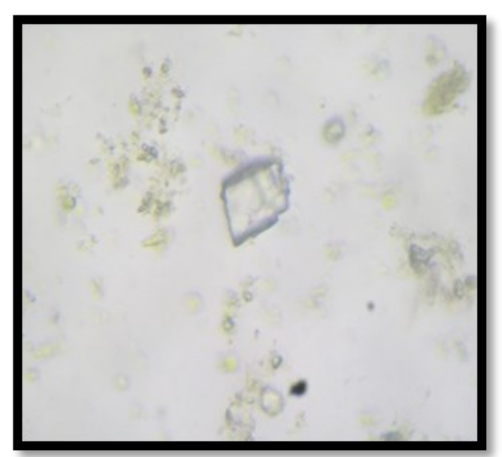

4b] Prismatic Crystal Of Calcium Oxalate

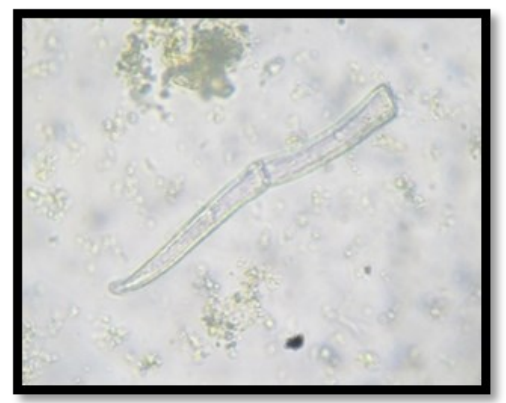

4e] Fragment of Multicellular Trichome

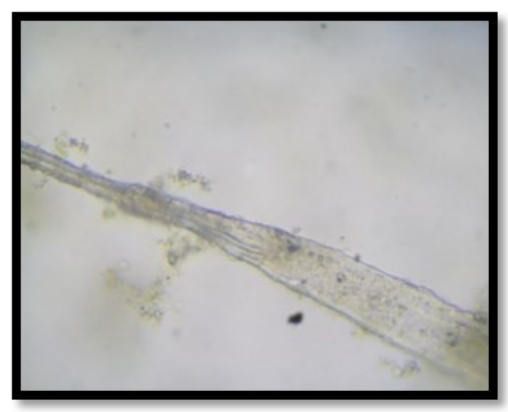

4h] Simple Fibre

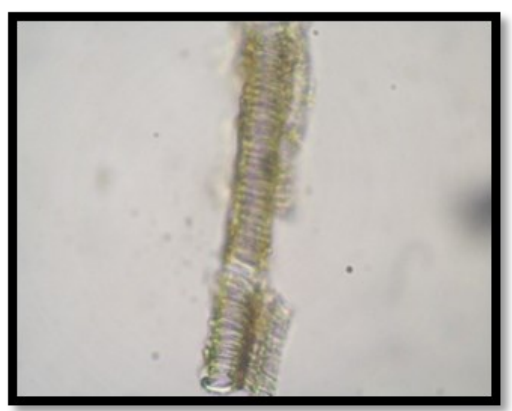

4k] Annular Vessels

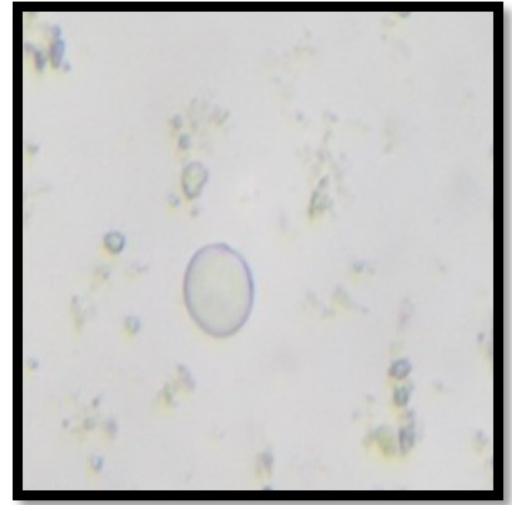

4c] Oil Globule

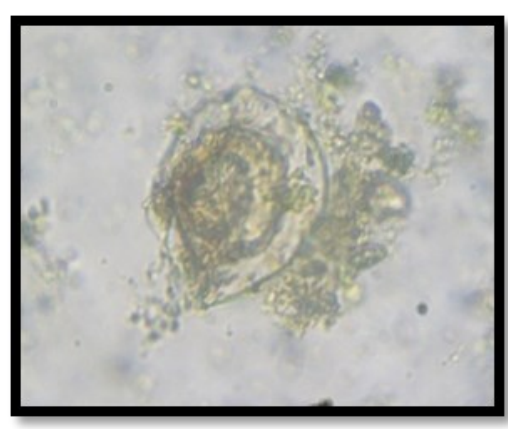

4f] Disturb Granular Trichome

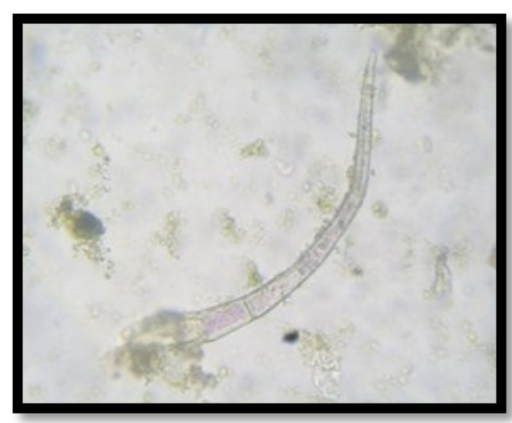

4i] Multicellular Trichome

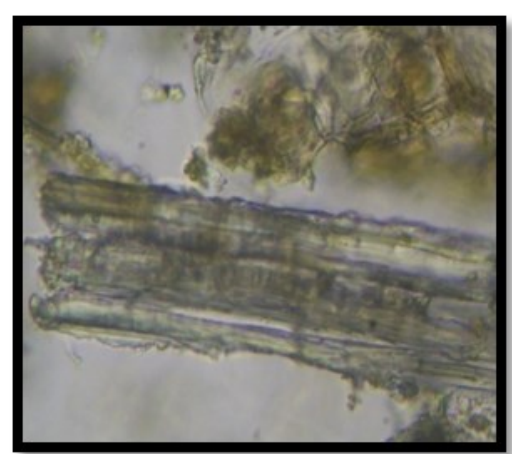

41] Group of Fibres 
Graph 1: Showing the results of HPTLC of Krushnatulasi at 254 wavelengths | Track 1, ID: Tulasi

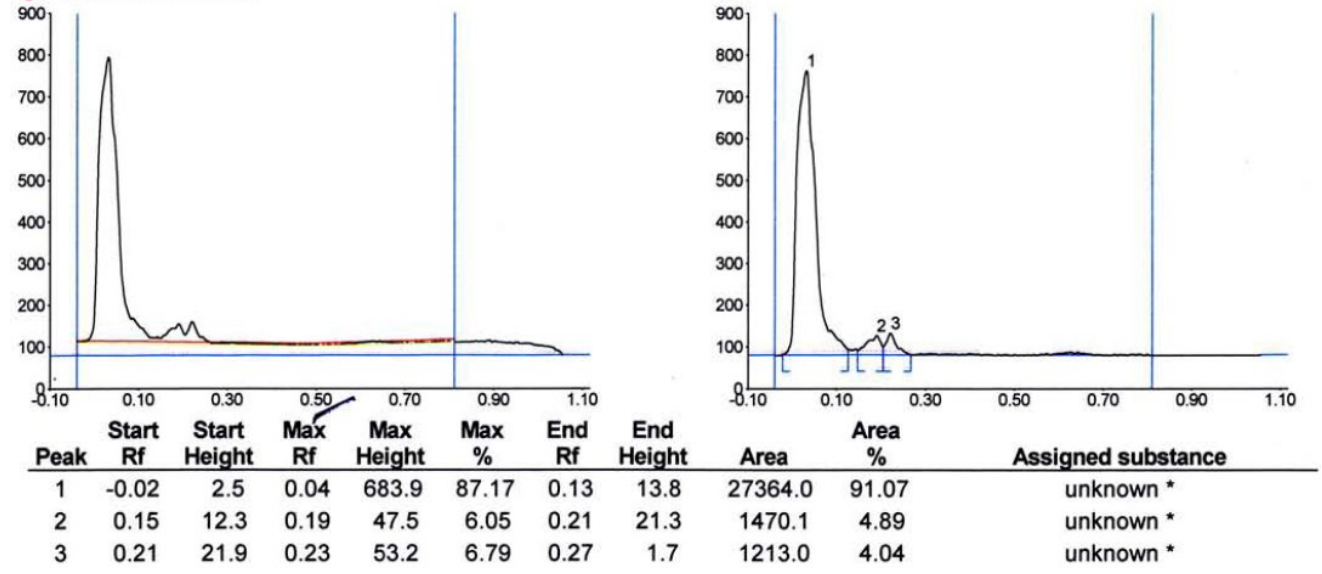

Graph 2: Showing the results of HPTLC of Krushnatulasi at 366 wavelengths

| Track 1, ID: Tulasi

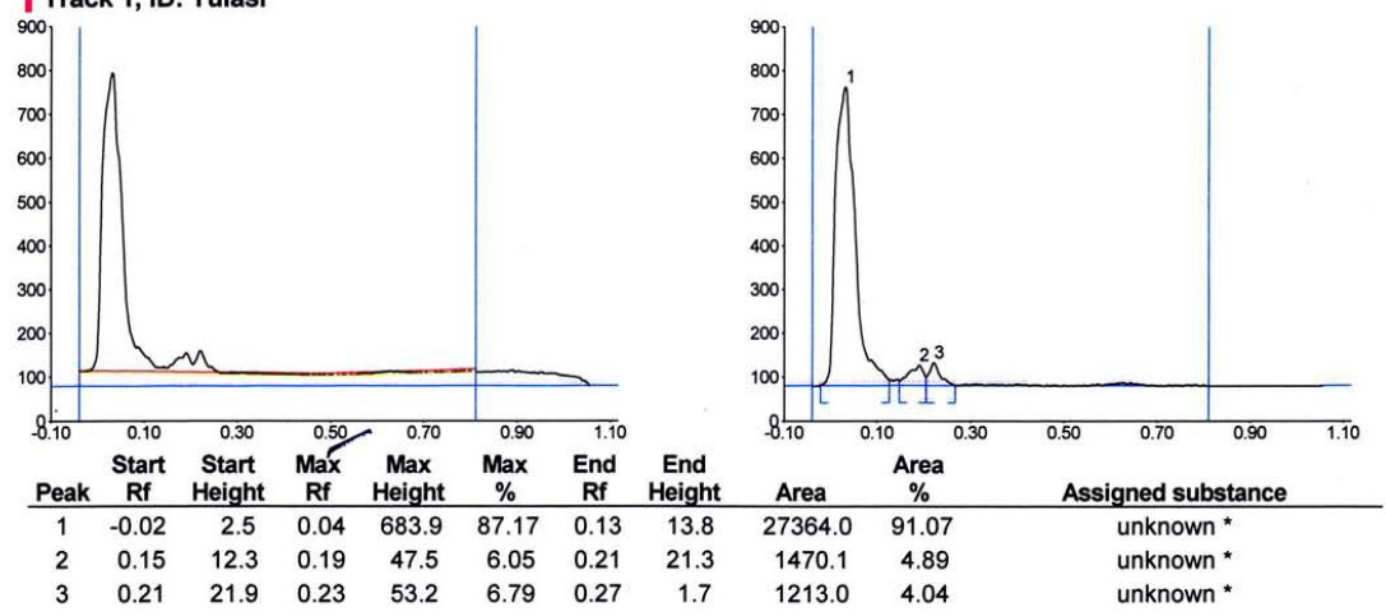

Graph 3: Showing the results of HPTLC of Krushnatulasi at 416 wavelengths

| Track 1, ID: Tulasi

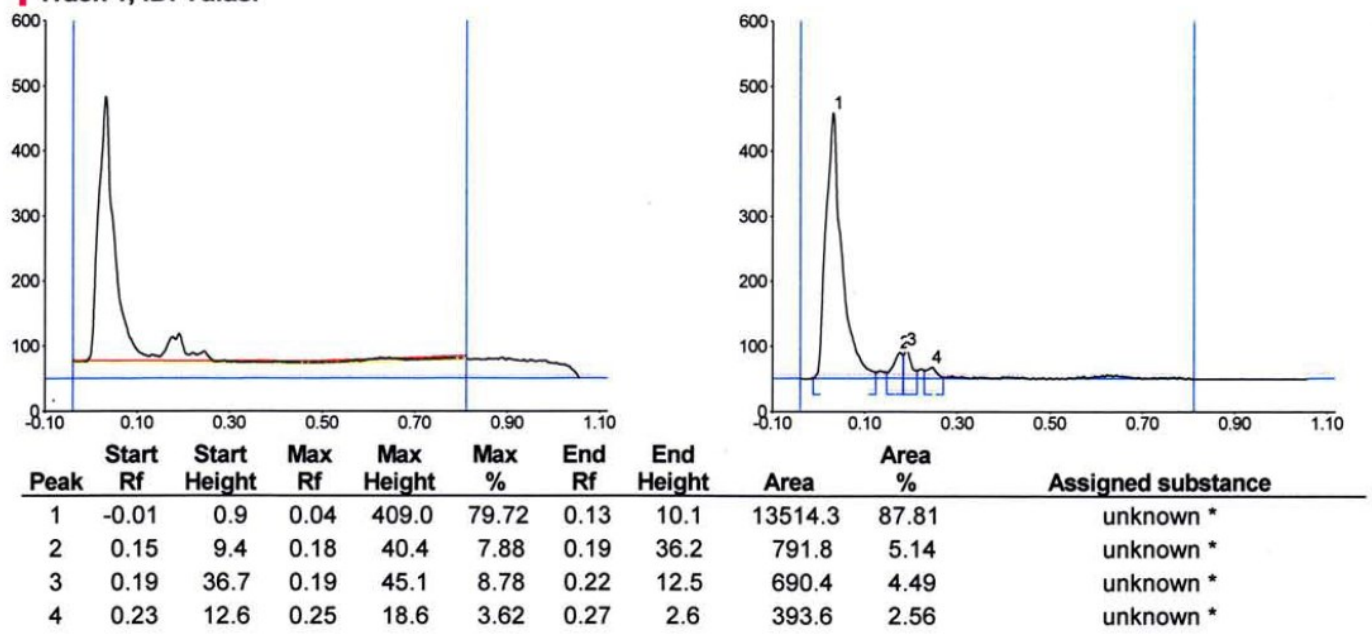

